\title{
Making work pay: increasing labour supply of secondary earners in low income families with children
}

\author{
Anna Kurowska', Michał Myck², Katharina Wrohlich ${ }^{3}$
}

\begin{abstract}
In-work support through the tax-benefit system has proved to be an effective way of increasing the labor supply of lone mothers and first earners in couples in a number of OECD countries. At the same time, these instruments usually create negative employment incentives for secondary earners. This in turn reduces the potential of in-work support to address the joint objectives of higher employment and lower poverty levels. In this paper, we present a simulation exercise to examine labor supply implications of a diverse set of possible reforms to the main elements of tax and benefit support for families with children. We set the analysis in the context of the Polish tax and benefit system and show how an adequate combination of increased generosity of support with the introduction of a "double earner" premium may result in an increased labor supply of first and second earners in couples. The simulated reactions are concentrated in the lower half of the income distribution, thus increasing the potential of in-work support to alleviate poverty.
\end{abstract}

KEY WORDS: $\quad$ labor supply, tax-benefit system, microsimulation, family policy

JEL Classification: J22, J13, J18

${ }^{1}$ University of Warsaw - Institute of Social Policy, Poland; ${ }^{2}$ Centre for Economic Analysis CenEA, Poland; ${ }^{3}$ German Institute for Economic Research, DIW-Berlin, Germany

\section{Introduction}

Over the past few decades, in-work support has been introduced in many OECD countries with the objective to jointly address the goals of poverty reduction and increase employment, and it has been shown that these policies have positive effects on the labor supply of lone mothers and primary earners in couples (see, e.g., Blundell, 2000; Brewer, Duncan, Shephard \& Su-

Correspondence concerning this article should be addressed to: Anna Kurowska, University of Warsaw - Institute of Social Policy, Nowy Świat 67, room 110, Warszawa 00-927, Poland. E-mail: a.kurowska@uw.edu.pl arez, 2006). However, such in-work financial support often goes along with strong negative work incentives for secondary earners (see, e.g., Brewer et al., 2006; Eissa \& Hoynes, 2004; Haan \& Myck, 2007). This is because 'classic' in-work support such as the Earned Income Tax Credit (EITC) in the US or the Working Families' Tax Credit (WFTC) in the UK are meanstested at the family level. As a result, these instruments may generate strong income effects on secondary earners, while high taper rates on their employment income imply high marginal tax rates. These in turn result in disincentive effects at the extensive and intensive margin, respectively. 
To avoid these negative incentives for secondary earners, some countries have introduced individualbased in-work credits, e.g., Belgian 'Employment Bonus', (Bargain, Caliendo, Haan, \& Orsini, 2010) or subsidies to social security contributions of lowincome employees, e.g., German 'Mini-Jobs', (Steiner \& Wrohlich, 2005). While these schemes help to avoid high marginal tax rates on secondary earners, they may still discourage them from taking up work due to income effects and are generally less efficient in targeting poverty, as some of the low-wage workers live in medium or high-income households.

Recent policy has focused on families with children in Poland, resulting to a large extent from one of the lowest fertility rates in OECD countries, has led to an introduction of a number of policies that increased in-work incomes of families with children. These include a generous income tax credit for families with children in 2007 and its extension in 2014 with increased generosity for low-income families as well as a recent reform that changed a point withdrawal system in means-tested family benefits into tapered reduction. On top of these, April 2016 saw an introduction of a major reform of support for families (the so-called 500+ Program), which implemented a universal benefit of 500 PLN per month for the second and subsequent children aged 0-17 with a means-tested top up for first children for low income families. Until now, however, successive governments have not considered any instruments aimed specifically at two-earner households, and the point withdrawal of the $500+$ benefits will add to second earner disincentive effects. As we show in this paper, it is the focus of support on second-earners that can effectively lead to a combination of improvement in the material conditions of low-income families and employment among parents. To illustrate this, we use the example of the Polish system of support for families with children as it was implemented in 2009 (i.e., before the extended child tax credit, the withdrawal taper in family benefits and the 500+ program) and examine the potential ways to improve its implications for labor market incentives with a particular focus on the ways to encourage employment of secondary earners. In our analysis, we shed new light on the issue highlighting the trade-offs involved. Similar to Figari (2015), the exercise conducted in this paper goes beyond the well-documented trade-off between equity and labor market objectives (Adam \& Browne 2010; Blundell, Duncan, McCrae, \& Meghir 2000; Duncan \& Giles, 1996; Immervoll \& Barber 2006; Immervoll, Kleven, Kreiner, \& Verdelin, 2011; Jara \& Tumino 2013) and addresses the less prominent concerns, namely, the need to balance first and second earner incentives and labor supply effects by the level of household income. The analysis focuses on familylevel rather than individualized financial support given the less precise targeting of support toward lowincome households in the latter case (e.g., Bargain \& Orsini, 2006; Figari 2015). All the modeled alternatives have been calibrated in such a way that they are ex post (i.e., after labor supply adjustments) equally costly to the state budget. We concentrate our analysis on couples with children for three important reasons. First, the negative work incentives of in-work support concern second earners in couples (and not lone mothers). Second, the gender employment gaps in Poland, as in many other countries of Central and Eastern Europe (CEE), are strongly related to the demographic structure of the household and childcare responsibilities and are particularly visible among men and women with children (Myck, Kurowska \& Kundera, 2013; Kurowska, Myck \& Wrohlich, 2012). Third, poverty in Poland and other CEE countries is particularly high among families with children (European Commission, 2008).

The paper is structured as follows. In Section 2, we provide a brief background on the system of financial support for families with children in Poland as it operated in 2009. Section 3 describes the data we use and the modeling approach, while in Section 4 we present the results of the simulations. Section 5 offers conclusions and policy implications.

\section{Background for microsimulations: system of financial support for families in Poland (2009)}

The Polish system of financial support for families with children comprises two principal components: the means-tested Family Benefits (FB), and a nonrefundable Child Tax Credit (CTC). The first element is composed of the basic Family Allowance (FA) with additional supplements. ${ }^{1}$ Eligibility criteria for Family Benefits assess family income with reference to 
A. One earner, budget constraint

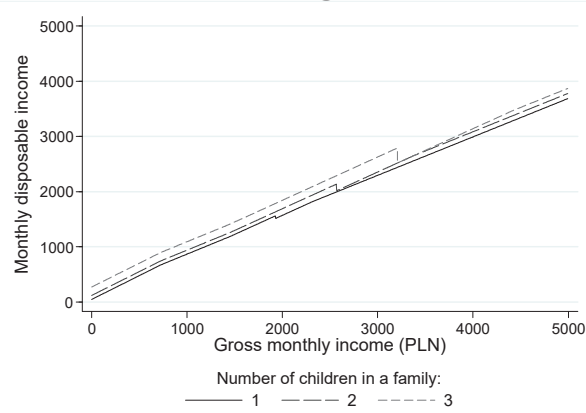

C. Two earners, budget constraint

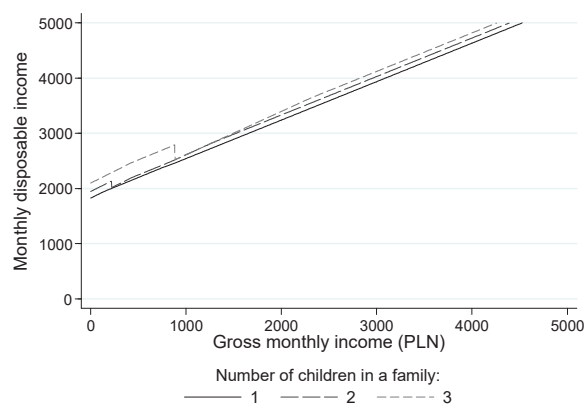

B. One earner, total family support

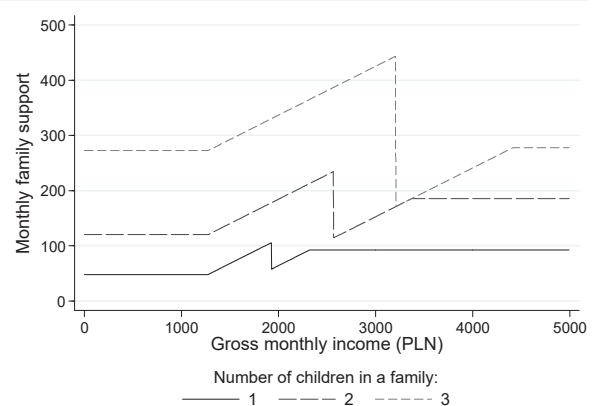

D. Two earners, total family support

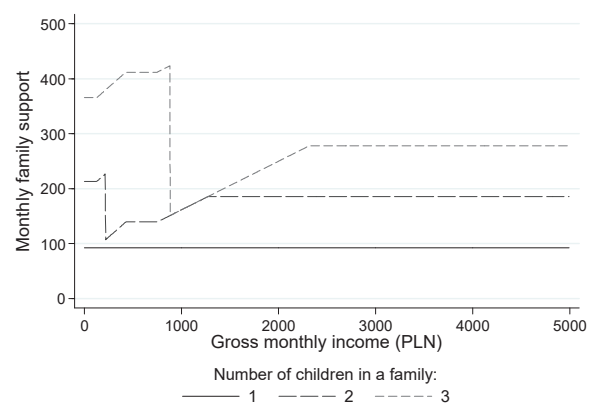

Figure 1. Gross income and family support - 2009

Source: Authors' calculations using the SIMPL microsimulation model (V4S3_12). For second earner's figures, earnings of the first earner are fixed at 2,326.31 PLN (equivalent to 75\% of gross monthly mean wage in 2009).

a threshold, which - prior to the reform in 2015 once exceeded makes the family ineligible to claim the benefits. Such a 'point withdrawal' of benefits implies very high effective marginal tax rates and has significant implications for average effective rates of tax (see Myck et al., 2013; Myck et al., 2015). The CTC is available to families with children who are subject to progressive income taxation. Eligibility to the credit is conditional on sufficient level of taxable income and starts approximately at the level of annual income corresponding to full time employment at the minimum wage. In 2009, the maximum value of the credit per child was 92,70 PLN (€20,70²) per month, and it was not withdrawn for high-income families. Low-tomiddle income families can combine receiving support from both sources. The FB and the CTC are assessed on the basis of joint family income, and as such, imply the well-known consequences in the form of discouraging employment of secondary earners in couples (e.g., Bargain \& Orsini, 2006, Brewer et al., 2006; Blundell et al., 2000; Duncan \& Giles, 1996; Haan \& Myck, 2007; Immervoll et al., 2011). Research on the consequences of such features using data for other countries suggests that they play an important role in determining 
the pattern of employment among couples (Dearing, Hofer, Lietz, Winter-Ebmer, \& Wrohlich, 2007; Steiner \& Wrohlich, 2005).

The described features of the 2009 system are illustrated in Figure 1A, where we show the budget constraint for a single earner couple with one, two and three children, and in Figure 1B, which for the same families shows the relationship between gross income and monthly total family support - the sum of the FB and the CTC. The corresponding relationship for the second earner in couples with children is given in Figures 1C and 1D. As we see in the case of the figures for single earners, the combination of FB and CTC results in similar levels of support given to low and high-income families. The highest amounts of support are paid to families with incomes just below the FB eligibility threshold where they can claim part of the CTC and still receive the full amounts of Family Benefits (in the case of single earner couples, this occurs at the level of 1,930 PLN for families with one child, 2,570 PLN for families with two children and 3,210 PLN for families with three children). The general structure of family support in 2009 was retained until 2014 when the CTC was made more generous to the lowest income families through the possibility of claiming it not only against income tax but also against social insurance contributions. Additionally, the government implemented tapered withdrawal of Family Benefits, which came into force in 2016. However, neither of these reforms introduces any specific second-earner incentives.

\section{Data and Methods}

\subsection{The Polish Household Budget Survey}

We base our analysis on the data from the Polish Household Budget Survey (PHBS) for 2009. This survey is conducted annually by the Polish Central Statistical Office and covers detailed information on demographics, incomes and household expenditure. The 2009 PHBS database includes information on a representative sample of 37,412 private households $(107,967$ individuals).

For the purpose of our analysis, we choose couples in labor supply flexible households (men aged 18-59; women 18-54; not self-employed or student; not re- ceiving disability or retirement pensions). The final sample comprises 10,623 couples, of which $76 \%$ have at least one child and $11 \%$ three or more children. In the baseline scenario, $62.4 \%$ are two-earner couples.

\subsection{Simulated reform scenarios: employment support through financial incentives}

To address the research questions outlined in the introduction and to illustrate the implication of changes in financial incentives for families, we design four alternative reform scenarios: two implementing changes to the system of Family Benefits and two introducing modifications to the functioning of the CTC. The exercise is constructed in such a way that the policies are easily implementable extensions of existing instruments and for each policy area, they include an increase in the generosity of the system or combine increase in generosity with a "double earner" premium. With regard to comparability of the policy effects, the modeled changes have been calibrated in such a way that they are ex post (i.e., after labor supply adjustments) equally costly to the government (approximately 0.5 bn PLN, i.e., $€ 110 \mathrm{mn}$ ).

The following reforms are analyzed:

- System 1: introduction of tapered withdrawal of $\mathrm{FB}$ at the rate of $55 \%$ (same as the rate of the UK's WFTC) instead of the current point withdrawal;

- System 2: introduction of tapered withdrawal of FB (at 55\%) combined with a "double earner" premium in the form of extended withdrawal threshold conditional on the work of both parents (they need to earn at least $80 \%$ of the national minimum wage (NMW, equal to 1276 PLN, €285,50 euro, per month in 2009));

- System 3: increase in the maximum value of the CTC from 92.70 PLN per month per child to 107 PLN per month;

- System 4: introduction of a "double earner" premium through the CTC in the form of an additional value of the CTC (92.70 PLN per month) for couples where both parents earn at least $175 \%$ of the NMW.

The implications of these reforms for the level of support through the two elements of the system for stylized households are presented in Figure 2. In Systems 1 and 2, the common feature is that the point with- 


\section{Family Benefits}

\section{A. First earner, family with two children}

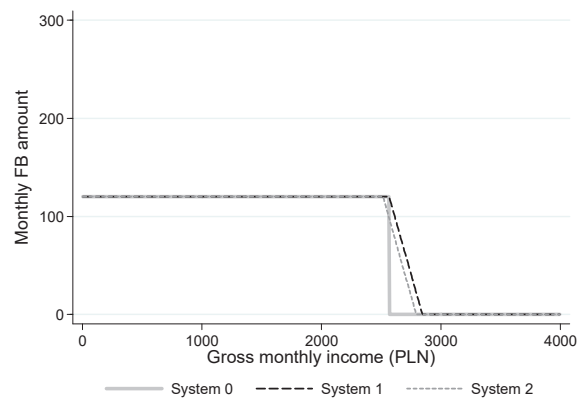

B. Second earner, family with three children

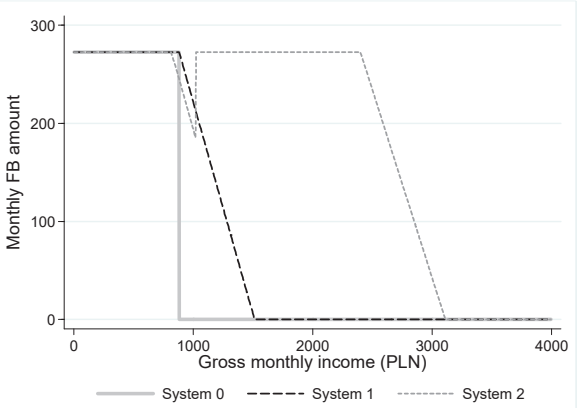

Child Tax Credit

C. First earner, family with two children

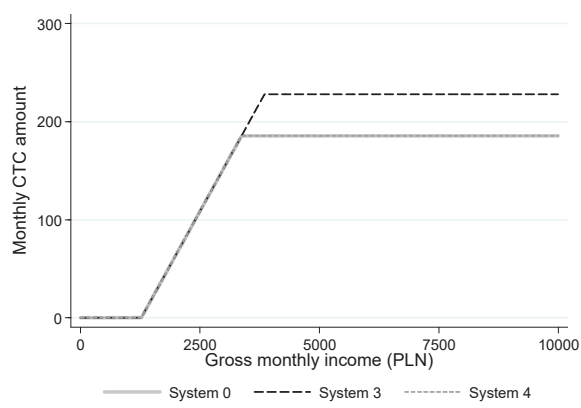

D. Second earner, family with three children

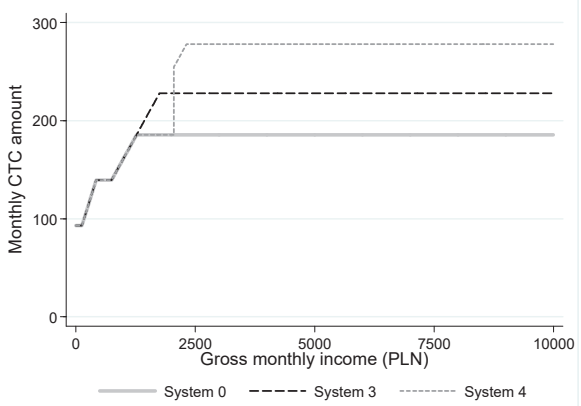

Figure 2. Level of support under the base and reformed scenarios

Source: Authors' calculations using the SIMPL microsimulation model (V4S3_12). For second earner's figures, earnings of the first earner are fixed at 2,326.31 PLN (equivalent to $75 \%$ of gross monthly mean wage in 2009).

drawal of benefits at the level of net monthly income of 504 PLN per person is substituted with gradual withdrawal of the benefits. Figure $2 \mathrm{~B}$ shows how the "double earner" premium of System 2 is designed to operate. With the first earner employed at 2,330 PLN per month, initially the benefits begin to be withdrawn when the second earner's gross salary crosses the threshold of 810 PLN. However, when they reach the required level of $80 \%$ of the NMW (approximately 1020 PLN), the "double earner" premium kicks in, and the withdrawal threshold is increased to 2,400 PLN. This implies that this family continues to receive Family Benefits up to the level of income of the second earner of $3,110 \mathrm{PL}$ per month (to equate 
Table 1. Labor supply participation elasticities

\begin{tabular}{lccc}
\hline & Own net wage & Cross net wage & Total net wage \\
\hline Men & 0.287 & -0.026 & 0.272 \\
Women & 0.696 & -0.053 & 0.659 \\
\hline
\end{tabular}

Source: Adapted from "Stability of elasticity estimates in the context of significant changes in labour market incentives" by Myck (2014). Retrieved from http://www.cenea.org.pl/images/stories/pdf/working_papers/Myck_CenEA_WP0114.pdf.

the costs of System 2 and System 1, the baseline withdrawal threshold in System 2 is reduced from 504 to 494 PLN per person). Figures 2C and 2D demonstrate the operation of Systems 3 and 4. Under System 3, the one-earner family with two children (Figure 2C) begins to see benefits of higher levels of the tax credit once gross earnings exceed 3,380 per month, while the two-earner family with three children when the monthly gross earnings of the second earner exceed 1,280 PLN. Under System 4 the two-earner couple with three children will see their CTC level jump to 255 PLN per month once the second earner exceeds the required threshold of $175 \%$ of NMW (2,230 PLN). As we see in Figure 2D, the "double earner" premium, even in the case of a family with three children, is higher compared to the additional level of the credit for each of the children in the family resulting from the design of System 3. The "double earner" earnings thresholds under Systems 2 and 4 have been designed in such a way that they affect different sections of the earnings distribution and account for other elements of the system in such a way that they target a sufficiently large proportion of families.

\subsection{Modeling labor supply response to the simulated reforms}

To model the labor supply response to the simulated reforms, we apply the standard static discrete choice labor supply model along the lines of van Soest (1995), Blundell et al. (2000), Steiner \& Wrohlich (2005) and Haan \& Myck (2007). Due to lack of information on precise hours worked in the data, we model the labor supply choice between not working, working part time and working full time. Incomes in the modeled labor market scenarios are computed using the microsimu- lation model SIMPL. ${ }^{3}$ The utility function is quadratic in household consumption $\left(c_{i}\right)$ and includes dummy variables for participation $\left(w_{i}^{m}\right.$ and $w_{i}^{f}$ for men and women respectively), part time dummies $\left(p t_{i}^{m}\right.$ and $\left.p t_{i}^{f}\right)$ and their interactions. The deterministic part of the utility function takes the following form:

$U_{i j}\left(c_{i j}, w_{i j}^{m}, w_{i j}^{f}\right)=$

$=\beta_{1 i} c_{i j}+\beta_{2}\left(c_{i j}\right)^{2}+\beta_{3 m i} w_{i j}^{m}+\beta_{3 f i} w_{i j}^{f}+\beta_{4 m} p t_{i j}^{m}+\beta_{4 f} p t_{i j}^{f}+$

$+\gamma_{1 j} c_{i j} w_{i j}^{f}+\gamma_{1 m} c_{i j} w_{i j}^{m}+\gamma_{2 f} c_{i j} p t_{i j}^{f}+\gamma_{2 m} c_{i j} p t_{i j}^{m}+\gamma_{3 m} w_{i j}^{m} w_{i j}^{f}$

and parameters $\beta_{1 i}, \beta_{3 m i}$ and $\beta_{3 f i}$ are allowed to vary with characteristics (taste shifters). Our estimates account unobserved heterogeneity through estimating a mass point on $\beta_{c i}$. The budget constraint is determined by wages $\left(\omega_{\mathrm{i}}\right)$, work status $\left(w_{i j}\right)$, out-of-work incomes $\left(y_{i}\right)$, household characteristics $\left(X_{i}\right)$ and the tax and benefit function $(\phi)$ :

$c_{i j}=\phi\left[\omega_{i}^{m}, \omega_{i}^{f}, w_{i j}^{m}, w_{i j}^{f}, X_{i}, y_{i}\right]$.

\section{Results: labor supply estimates and employment effects}

The simulated average labor supply elasticities separately for men and women are presented in Table 1 (for estimation details and derivation of elasticities, see Myck, 2014). The own net wage elasticity for women is positive and more than two times higher for women than for man. For both genders, the cross net wage elasticity is negative, but small and again stronger for women than for men. 


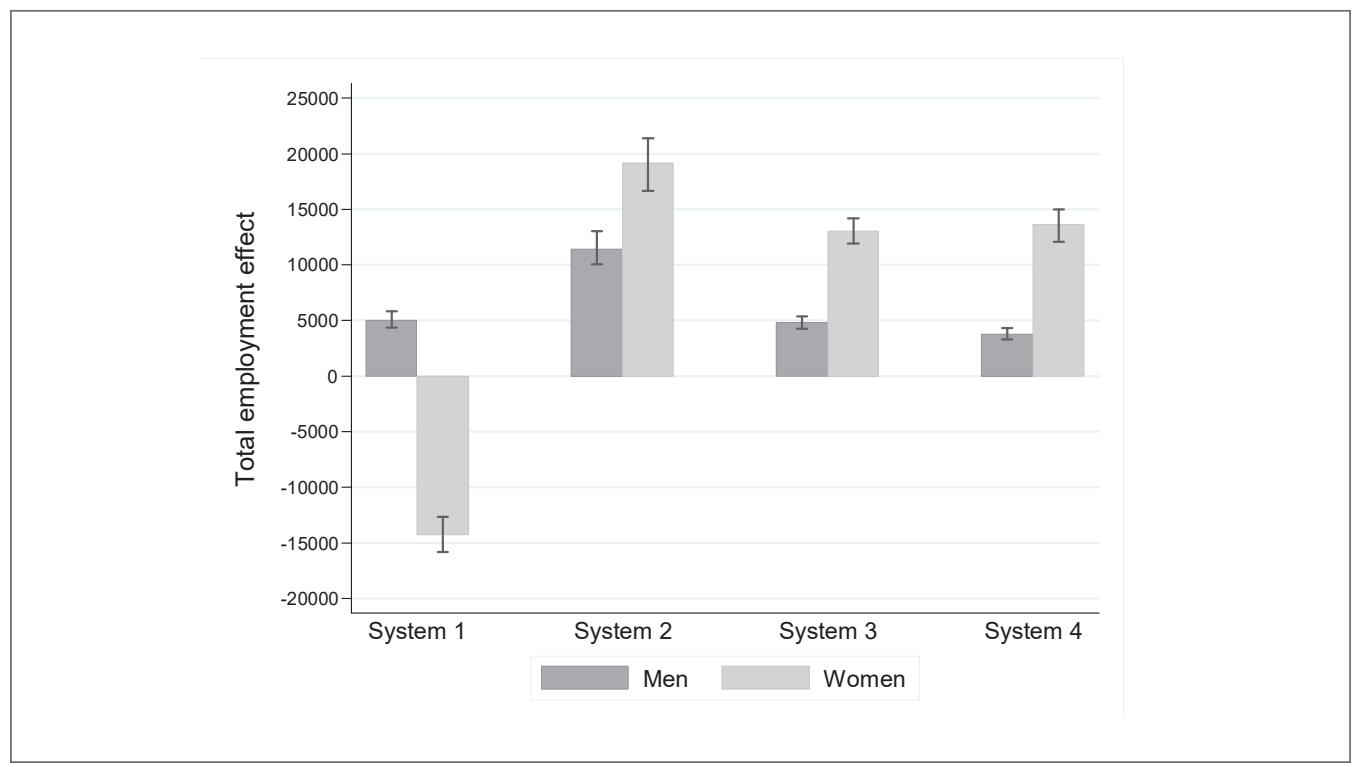

Figure 3. Employment effects of modeled reforms

Source: own calculations based on PHBS-2009 data and SIMPL microsimulation model.

Table 2. Labor supply effects of modeled reforms

\begin{tabular}{|c|c|c|c|c|}
\hline & System 1 & System 2 & System 3 & System 4 \\
\hline \multicolumn{5}{|c|}{ In thousands: } \\
\hline Men & 5.0 & 11.4 & 4.8 & 3.8 \\
\hline Women & -14.3 & 19.2 & 13.0 & 13.6 \\
\hline Total: & -9.3 & 30.6 & 17.8 & 17.4 \\
\hline \multicolumn{5}{|c|}{ As percentage of parents in couples: } \\
\hline Men & 0.17 & 0.38 & 0.16 & 0.13 \\
\hline Women & -0.48 & 0.64 & 0.44 & 0.46 \\
\hline Total: & -0.16 & 0.51 & 0.30 & 0.29 \\
\hline
\end{tabular}

Total by income quintile (in thousands):

$\begin{array}{lllll}\text { Q1 } & 0.0 & 16.1 & 4.1 & 0.8 \\ \text { Q2 } & -3.2 & 9.2 & 4.7 & 1.8 \\ \text { Q3 } & -3.8 & 3.1 & 4.7 & 3.3 \\ \text { Q4 } & -1.6 & 1.6 & 3.0 & 5.0 \\ \text { Q5 } & -0.7 & 0.4 & 1.3 & 6.5\end{array}$

Source: own calculations based on PHBS-2009 data and SIMPL microsimulation model. Absolute values computed using grossing up weights provided by the Central Statistical Office. 
The labor supply effects of the reforms are presented in Figure 3 and Table 2 separately for men and women. In the first reform scenario, the tapered withdrawal of Family Benefits, designed to ease the very high effective marginal tax rates, increases the labor supply of men (in most cases, first earners) but at the same time, diminishes the labor supply among women with a negative net effect of approximately 9,000 individuals, which is approximately $0.2 \%$ of all parents in couples. This is a classic example of the well-documented negative second earner effect of greater generosity of means tested support and has the well-known implication of increasing the proportion of one-earner households. The latter effect is due to, on the one hand, increased activity in no-earner couples, and on the other hand, the reduced labor supply among two-earner households

However, the negative labor supply effects among women are fully overturned under System 2 reform, which combines tapered FB withdrawal with a "double-earner" premium (see Figure 3). The total labor supply effect is approximately 31,000 individuals, i.e., approximately $0,5 \%$ of parents in couples, and the labor supply of women increases by approximately 19,000 ( $0.6 \%$ of mothers in couples).

The two reforms of support through the Child Tax Credit (System 3 and 4) have similar total effects on the labor supply of approximately 4000 for fathers $(0.15 \%)$ and 13000 for mothers (0.45\%). The labor supply effects of these reforms, however, affect different sections of the household income distribution. This is depicted in the second panel of Table 2, where for each reform we document the labor supply changes by baseline income quintile. In the case of System 3 , the effect on the labor market is concentrated in the lower and middle quintiles, while System 4 affects the labor supply of households primarily in higher quintiles.

The quintile distribution of labor supply reactions sheds additional light on the effects of Systems 1 and 2. Labor supply reductions in the case of System 1 are concentrated in the second and third quintile, i.e., in the parts of the distribution where low income double earner families are located, while the positive reaction to System 2 comes primarily from the lower end of the distribution, and in particular, from the first quintile.

\section{Conclusions}

We have presented an exercise in simulating labor supply reactions of a diverse set of hypothetical reforms to the system of financial support for families with children, which bring a number of general implications for designing tax-benefit systems. As has been demonstrated earlier (e.g., Brewer et al., 2006, Eissa \& Hoynes, 2004; Haan \& Myck, 2007), increases in the generosity of means-tested support without specific second earner premiums results in the overall reduction of the labor supply among couples, although such reforms usually reduce the number of so-called workless households. In this article, we have shown how an adequate combination of the increase in the generosity of the tax-benefit system with the introduction of a "double earner" premium may balance the employment incentives for first and second earners and concentrate the labor supply effects in the lowest quintile of the income distribution. Naturally, as in the case of all labor supply simulations, there may be additional constraints, which might influence the actual effects of specific policies if implemented in reality. These include such aspects as existence of suitable employment positions, hours constraints, benefit take-up issues or the availability of childcare (Bargain et al., 2010; Brewer et al., 2006; Haan \& Wrohlich, 2011; Wrohlich, 2011). More specific and extended labor supply models based on much more detailed data would be necessary to address these concerns, although it seems that most of them would apply equally strongly to the different hypothetical scenarios modeled in our exercise.

In our labor supply exercise, the small negative effects of the introduction of a tapered withdrawal of Family Benefits, simulated in the Polish tax and benefit system of 2009, turn strongly positive once a "doubleearner" premium is implemented on top of it while holding the cost of the modeled reforms constant. The resulting labor supply effects are in the range of 31000 individuals and could increase employment of men by approximately $0.3 \mathrm{pp}$ and that of women by $0.5 \mathrm{pp}$. The majority of the generated labor supply response is concentrated among households from the bottom quintile of the income distribution. In contrast, the "double earner" premium implemented in the Child Tax Credit, which benefits middle and high-income families, has a much lower effect on the labor supply and affects employment mainly in the higher part 
of the income distribution. This is due to the way in which the CTC eligibility is allocated and due to the modeled requirements for the levels of income of both partners to qualify for the premium.

The presented exercise shows that a redesign of lowincome support for families with children with explicit rewards for two-earner couples could be an efficient way to increase the labor force participation rates of mothers. Designing “double earner" premiums as elements of low-income means-tested support could be a successful means to reduce child poverty through the combination of direct support and higher labor market activity among parents.

\section{References}

Adam, S., \& Browne, J. (2010). Redistribution, Work Incentives and Thirty Years of UK Tax and Benefit Reform. Institute for Fiscal Studies (Working Paper 10/24). Retrieved from https://www.ifs.org. uk/wps/wp1024.pdf

Bargain, O., \& Orsini, K. (2006). In-work policies in Europe: Killing two birds with one stone. Labour Economics, 6(13), 667-693.

Bargain, O., Caliendo, M., Haan. P., \& Orsini, K. (2010). Making work pay in a rationed labor market. Journal of Population Economics, 1(21), 323-351.

Blundell, R.W. (2000). Work incentives and in-work benefit reforms: A review. Oxford Review of Economic Policy, 16(1), 27-44.

Blundell, R., Duncan, A., McCrae, J., \& Meghir, C. (2000). The labour market impact of the working families' tax credit. Fiscal Studies, 21(1), 75-103.

Brewer, M., Duncan, A., Shephard, A., \& Suarez, M. J. (2006). Did working families tax credit work? The impact of in-work support on labour supply in Great Britain. Labour Economics, 13(6), 699-720.

Dearing, H., Hofer, H., Lietz, C., Winter-Ebmer, R., \& Wrohlich, K. (2007). Why are mothers working longer hours in Austria than in Germany? A comparative microsimulation study, Fiscal Studies, 28(4), 463-495.

Domitrz, A., Myck, M., Morawski, L., \& Semeniuk A. (2013). Dystrybutywny wpływ reform podatkowoświadczeniowych wprowadzonych w latach 2006-2011 [Distributive Effect of Tax and Benefit Reforms Implemented in the Period 2006-2011]. Bank i Kredyt [Bank \& Credit], 44(3), 261-286.
Duncan, A., \& Giles, C. (1996). Labour supply incentives and recent family credit reforms. The Economic Journal, 106(434), 142-155.

Eissa, N., \& Hoynes, H. (2004). Taxes and the labor market participation of married couples: The earned income tax credit. Journal of Public Economics, 88(9-10), 1931-1958.

European Commission (2008). Child poverty and wellbeing in the EU. Current status and way forward. Belgium: Office for Official Publications of the European Union.

Figari, F. (2015). From housewives to independent earners: How the tax system can help women to work in a context of strong familialism. Journal of Social Policy, 44(1), 63-82.

Haan, P., \& Myck, M. (2007). Apply with caution: Introducing UK-style in-work support in Germany. Fiscal Studies, 28(1), 43-72.

Haan, P., \& Myck, M. (2010). Safety net still in transition: labour market incentive effects of social support in Poland and Germany. Bank i Kredyt [Bank \& Credit], 41(3), 5-34.

Haan, P., \& Myck, M. (2012). Multi-family households in a labour supply model: a calibration method with application to Poland. Applied Economics, 44(22), 2907 - 2919.

Haan, P., \& Wrohlich, K. (2011). Can child care encourage employment and fertility? Evidence from a structural model. Labour Economics, 18(4), 498-512.

Immervoll, H., \& Barber, D. (2006). Can parents afford to work? Childcare costs, tax-benefit policies and work incentives (Discussion Paper No. 1932). Institute for the Study of Labor. Retrieved from http://ftp.iza.org/dp1932.pdf

Immervoll, H., Kleven, H. J., Kreiner, C. T., \& Verdelin, N. (2011). An evaluation of the tax-transfer treatment of married couples in European countries. Journal of Public Economics, 95(11-12), 1485-1500.

Jara, H., \& Tumino, A. (2013). Tax-benefit systems, income distribution and work incentives in the European Union. International Journal of Microsimulation, 1(6), 27-62.

Levy, H., Morawski, L., \& Myck, M. (2012). EUROMOD Country Report - Poland. ISER, University of Essex. Retrieved from https://www.iser. 
essex.ac.uk/files/euromod/country-reports/CR PL2006-09_Final_12-2-2012.pdf

Kurowska, A., Myck, M., \& Wrohlich K. (2012). Family and labor market choices: Requirements to guide effective evidence-based policy (Discussion Paper No. 6846). Institute for the Study of Labor. Retrieved from http://ftp.iza.org/dp6846.pdf

Morawski, L., \& Myck, M. (2010). 'Klin'-ing up: Effects of Polish tax reforms on those in and on those out. Labour Economics, 17(3), 556-566.

Morawski, L., \& Myck, M. (2011). Distributional effects of the child tax credit in Poland and its potential reforms. Ekonomista [Economist], 6, 815-831.

Myck, M. (2014). Stability of elasticity estimates in the context of significant changes in labour market incentives (Working Paper 01/14). Centre for Economic Analysis. Retrieved from http://www. cenea.org.pl/images/stories/pdf/working_papers/ Myck_CenEA_WP0114.pdf

Myck, M., Domitrz, A., Morawski, L., \& Semeniuk, A. (2015). Financial incentives to work in the context of a complex reform package and growing wages: the Polish experience 2005-2011. Baltic Journal of Economics, 15(2), 99-121.

Myck, M., Kurowska, A., \& Kundera, A. (2013). Financial support for families with children and its trade-offs: balancing redistribution and parental work incentives. Baltic Journal of Economics, 13(2), 61-85.

Steiner, V., \& Wrohlich, K. (2005). Work incentives and labour supply effects of the ,mini-jobs'-reform in Germany. Empirica, 32(1), 91-116.

Van Soest, A. (1995). Structural models of family labor supply: A discrete choice approach. Journal of $\mathrm{Hu}$ man Resources, 30(1), 63-88.

Wrohlich, K. (2011). Labor supply and child care choices in a rationed child care market (Discussion Paper No. 1169). DIW Berlin, German Institute for Economic Research. Retrieved from

https://www.diw.de/documents/publikationen/73/ diw_01.c.388164.de/dp1169.pdf

\section{Endnotes}

1 For details of the Polish tax and benefit system, see, e.g., Domitrz, Myck, Morawski \& Semeniuk (2013), Levy, Morawski \& Myck (2012) or Morawski \& Myck (2010, 2011).
2 Throughout the paper, we use the exchange rate from June 31, 2009: $€ 1=4.47$ PLN.

3 For details concerning the model and for examples of its earlier applications, see, e.g., Bargain et al. (2010), Haan \& Myck (2010; 2012), Morawski \& Myck (2010; 2011).

\section{Acknowledgments:}

This article was written with financial support from the Foundation for Polish Science (Parent-Bridge Program) as part of the project "Joint influences of family and labor market policies on labor market participation and fertility decisions of men and women" directed by Anna Kurowska. Data used in the analysis have been provided by the Polish Central Statistical Office (GUS), which takes no responsibility for the analysis and interpretation of the results. We are grateful to Michał Kundera for assistance with microsimulation analysis. The usual disclaimer applies. 